\title{
ENDOGLUCANASE PRODUCTION WITH THE NEWLY ISOLATED Myceliophtora sp. I-1D3b IN A PACKED BED SOLID STATE FERMENTOR
}

\author{
A. I. Zanelato ${ }^{1}$, V. M. Shiota ${ }^{1}$, E. Gomes ${ }^{2}$; R. da Silva ${ }^{2}$; J. C. Thoméo ${ }^{1 *}$ \\ ${ }^{1}$ Departamento de Engenharia e Tecnologia de Alimentos, Instituto de Biociências, Letras e Ciências Exatas, Universidade \\ Estadual Paulista, São José do Rio Preto, SP, Brasil; ${ }^{2}$ Laboratório de Bioquímica e Microbiologia Aplicada, Instituto de \\ Biociências, Letras e Ciências Exatas, Universidade Estadual Paulista, São José do Rio Preto, SP, Brasil.
}

Submitted: March 30, 2011; Approved: June 07, 2012.

\begin{abstract}
This work is aimed to produce endoglucanase through solid state fermentation in a packed bed bioreactor with the use of the fungus Myceliophtora sp. I-1D3b using a mixture of wheat bran (WB) and sugar cane bagasse (SCB) as culture medium. Preliminary tests were performed in polypropylene plastic bags, controlling the variables temperature $\left(40,45\right.$, and $\left.50^{\circ} \mathrm{C}\right)$, initial moisture content $(75,80$, and $85 \%$, w.b.), and weight proportion SCB/WB (1:1, 7:3, and 9:1). The highest enzyme activities in plastic bags were obtained using the substrate proportion of $7: 3,50^{\circ} \mathrm{C}$ temperature, and $80 \%$ initial moisture content (878 U/grams of dry solid). High activities of filter-paper cellulase and xylanase were also obtained in plastic bags and some results are reported. For the packed bed experiments, the temperature ( 45 and $50^{\circ} \mathrm{C}$ ) and the air flow rate (80, 100 and $120 \mathrm{~L} / \mathrm{h})$ were the controlled variables. Activity of endoglucanase was similar to plastic bag tests. A longitudinal gradient of moisture content, was observed increasing from the bottom to the top of the reactor, even though the longitudinal enzyme activity profile was flat for almost the whole bed. Air flow rate did not affect enzyme activity, while experiments carried out at $50^{\circ} \mathrm{C}$ showed higher enzyme activities. The maximum temperature peak observed was at about $6^{\circ} \mathrm{C}$ above the process temperature.
\end{abstract}

Key words: Cellulase, xylanase, Myceliophthora sp., packed bed, solid state-fermentation

\section{INTRODUCTION}

Enzymes are used to catalyze reactions of several processes in many industrial sectors, such as textile, paper, pharmaceutical, food, and animal feed. More than 500 different enzymes are applied in more than 50 biotechnological processes (22). The market for enzymes is increasing and the demand for 2014 is estimated at US\$ 2.8 billion, only in the United States (8). However, the number of enzyme producers is small; Novozymes (Denmark), Gist Brocades (Holland), Amano (Japan), and Solvay, Pfizer and Genencor (United States) have $90 \%$ market share (2). Hence, development of new technologies for production of efficient enzymes on a large scale is strategic for developing countries.

Of particular interest for Brazilian researchers and industries are the enzymes to produce bioethanol from biomass since regular ethanol production generates about 167.8 million tons of sugar cane bagasse per year (25). Second generation

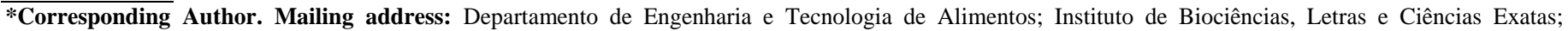
Universidade Estadual Paulista, São José do Rio Preto - SP, Brasil.; E-mail: thomeo@ibilce.unesp.br 
ethanol might be produced using a chemical method, but chemical residues would have to be treated, making the process less competitive. The enzymatic route is environmental friendly, but hydrolitic enzymes are expensive and there are few producers (21). The fibers of sugar cane bagasse are composed of $75 \%$ cellulose and hemicelluloses (5) that must be broken down with cellulases and hemicellulases to fermenting sugars.

Researches in SSF using thermophilic fungi to produce enzymes are increasing due to their intrinsic stability (17), and some thermophilic fungi have been recently reported as good producers of cellulolytic complexes enzymes in experiments carried out in glass flasks or in plastic bags $(4,6,9,10,15,16$, 26). However, it is not recommended that the optimal experimental conditions found in glass flasks tests be immediately transposed to the bioreactors tests, since the dynamic conditions observed in the fermentors are quite different (1). From several SSF bioreactor configurations, the fixed bed (FB) is cheaper, easier to operate, and demands lower maintenance. The main drawbacks of FB fermentors are thermal heterogeneity and moisture segregation, which turn the product distribution within the reactor non-uniform $(7,19)$.

This paper aimed the production of endoglucanase (CMCase) by SSF using the recently isolated thermophilic fungus Myceliophtora sp. I-1D3b, cultivated in sugar cane bagasse and wheat bran. The experiments were carried out in plastic bags and in a FB bioreactor; the results for CMCase activity were impressive in both experiments, indicating a very good potential for industrial application. Some results for total filter-paper cellulase (FPase) and xylanase were also significant and are presented.

\section{MATERIALS AND METHODS}

\section{Microorganism}

The thermophilic fungus Myceliophtora sp. I-1D3b was recently isolated from piles of sugar cane bagasse in an ethanol plant in Olímpia-SP, Brazil. The stock culture was maintained in agar-potato-dextrose (Oxoid) under water and mineral oil, at room temperature. For the experiments, the microorganism was cultivated in Petri dishes containing agar-Sabouraud-dextrose (Oxoid) during two days at $45^{\circ} \mathrm{C}$. The agar surface was then scraped and the spores were dispersed in the nutrient solution described below. A hemacytometer was used to count the spores, and the suspension concentration for inoculum was set at approximately $10^{7}$ spores $/ \mathrm{mL}$.

\section{Substrate for solid state fermentation}

Sugar cane bagasse (SCB) was kindly provided by Usina Cerradinho, Catandúva-SP, Brazil, which was washed with tap water to leach the residual sugar. The bagasse was oven dried at $80^{\circ} \mathrm{C}$ up to constant weight and ground in a knife mill. Only the fibers which passed through a $3 \mathrm{~mm}$ opening sieve and were restrained by a $1.44 \mathrm{~mm}$ sieve were used. Wheat bran (WB) was bought from local retailers, washed with tap water, oven dried at $60^{\circ} \mathrm{C}$ up to constant weight and used without additional treatments. Both substrates were kept under refrigeration at $2^{\circ} \mathrm{C}$ prior to use.

\section{Plastic bag experiments}

Plastic bags of polypropylene $(12 \mathrm{~cm} \times 20 \mathrm{~cm})$, containing $5 \mathrm{~g}$ of substrate, were used. A nutrient solution $(0.35 \%$ $\left(\mathrm{NH}_{4}\right)_{2} \mathrm{SO}_{4}, 0.3 \% \mathrm{KH}_{2} \mathrm{PO}_{4}, 0.05 \% \mathrm{MgSO}_{4} \times 7 \mathrm{H}_{2} \mathrm{O}, 0.05 \%$ $\mathrm{CaCl}_{2}, 0.1 \%$ Tween) at $\mathrm{pH} 5.0$ was added to the substrate up to the desired moisture content and sterilized in vertical retorts at $120^{\circ} \mathrm{C}$ during $20 \mathrm{~min}$.

Weight proportion of SCB/WB (1:1, 7:3, and 9:1), temperature $\left(40,45\right.$ and $\left.50^{\circ} \mathrm{C}\right)$, and initial moisture content (75, 80 and $85 \%$, w.b.) were the tested variables, according to a completely randomized full statistical design. The total fermentation period was $288 \mathrm{~h}$ and samples were withdrawn at each 48h. Some additional experiments were carried out using only SCB or WB as substrate in order to verify the influence of each individual solid material in the fermentation process.

The enzymes were extracted by adding $100 \mathrm{~mL}$ of distillated water (20mL of water/1g of dry solid) to the 
fermented material in an Erlenmeyer glass flask, which was stirred in an orbital shaker for 30min. The suspension was filtered and centrifuged at $10000 \mathrm{~g}$ at $5^{\circ} \mathrm{C}$ for $15 \mathrm{~min}$. The supernatant was used as crude enzyme solution for the enzyme activity tests.

\section{Packed bed experiments}

The packed bed was made of stainless steel and it was composed of up to five modules of $7.62 \mathrm{~cm}$ diameter and $10 \mathrm{~cm}$ length each. The modules were jacketed, through which water flowed at the same temperature as that of the air entrance. Between consecutive modules a nylon flange was placed, through which were inserted sheathed type $\mathrm{T}$ thermocouples (1.5mm diameter) whose tips were positioned at the central axis of the tube; hence a longitudinal temperature profile was obtained. The thermocouples were connected to a data acquisition system (National Instruments), managed by a LabView $^{\circledR}$ version 8.5 routine (National Instruments), and the signals were recorded in a computer. Two jacketed couplings inserted air and removed fermented gases from the bed. The packed bed was not sterilized for the experiments.

Air was provided by a radial compressor, filtered to restrain oil and filth, and conditioned with respect to temperature and relative humidity (95\%). No biological filter was necessary. The air entrance temperature $\left(45\right.$ and $\left.50^{\circ} \mathrm{C}\right)$ and the gas flow rate $(80,100$ and $120 \mathrm{~L} / \mathrm{h})$ were the controlled variables, chosen according to a completely randomized full statistical design.

The solid material necessary to pack each individual module was handled in plastic bags, where the nutrient solution and the spore suspension were added. Afterwards, the solid material was gently accommodated within each module in three portions of $15 \mathrm{~g}$ each, comprising $45 \mathrm{~g}$ of fermentation media per module. Nylon screens (1 $1 \mathrm{~mm}$ opening) were placed to restrain the solid material between consecutive samples. Independent experiments were carried out to evaluate longitudinal profiles of moisture content and endoglucanase activity. After the experiments, the fermented material was either placed in a convective oven at $80^{\circ} \mathrm{C}$ up to constant weight or treated to determine the enzyme activity. The proportion SCB/WB was set at 7:3 and $50^{\circ} \mathrm{C}$ after the plastic bag experiments.

\section{Determination of CMCase, FPase and xylanase activities}

The cellulases activities were based on Ghose (12) and the xylanase activity on Ghose and Bisaria (13). The activities of endoglucanase and xylanase were determined by reacting $0.1 \mathrm{~mL}$ of crude enzyme extract with $0.9 \mathrm{~mL}$ of substrate solution (carboxymethylcellulose 4\% - Sigma, for endoglucanase, and $0.9 \mathrm{~mL}$ of xylan $1 \%$ - Sigma, for xylanase). For FPase, a strip of Whatman $\mathrm{n}^{0} 1$ filter paper was added to $0.9 \mathrm{~mL}$ of $0.1 \mathrm{M}$ acetic acid/NaOH buffer (pH 5.0) and $0.1 \mathrm{~mL}$ of crude enzyme extract. For all enzymes, the mixtures were kept at $60^{\circ} \mathrm{C}$ for $10 \mathrm{~min}$. The released reducing sugars were estimated by the 3,5-dinitrosalicylic acid method (20). One unit of enzyme activity (U) was defined as the amount of enzyme that releases $1 \mu \mathrm{mol}$ of reducing sugars per minute in the assay conditions.

\section{RESULTS AND DISCUSSION}

All the results here presented for enzyme activity refers to the mass of dry solid before the fermentation process. For the plastic bag experiments, this is a simple task, since the mass of solid substrate is well defined. However, for the packed bed experiments it was necessary to divide the bed in portions of same weight $(15 \mathrm{~g})$ and all individual samples were used for enzyme activity analysis. Hence, moisture content experiments in packed bed were done separately. The results for enzyme activity will be presented in units per grams of dry solid (U/g.d.s.).

\section{Plastic bag experiments}

The endoglucanase activity as a function of the incubation time, for all SCB/WB proportions and temperatures, is shown Figure 1, when the initial moisture content was kept constant at 
$80 \%$. An increase of endoglucanase activity with respect to the incubation time was found, and the highest enzyme activities were obtained when the 7:3 SCB/WB proportion was used. The peak (878U/g.d.s.) was observed at $288 \mathrm{~h}$ of incubation time, even though a reasonable amount (669U/g.d.s.) was obtained as early as 96h. Some experiments were carried out for even longer periods (360h, data not shown) and it was observed that endoglucanase activity decreased steeply after 288 of cultivation.

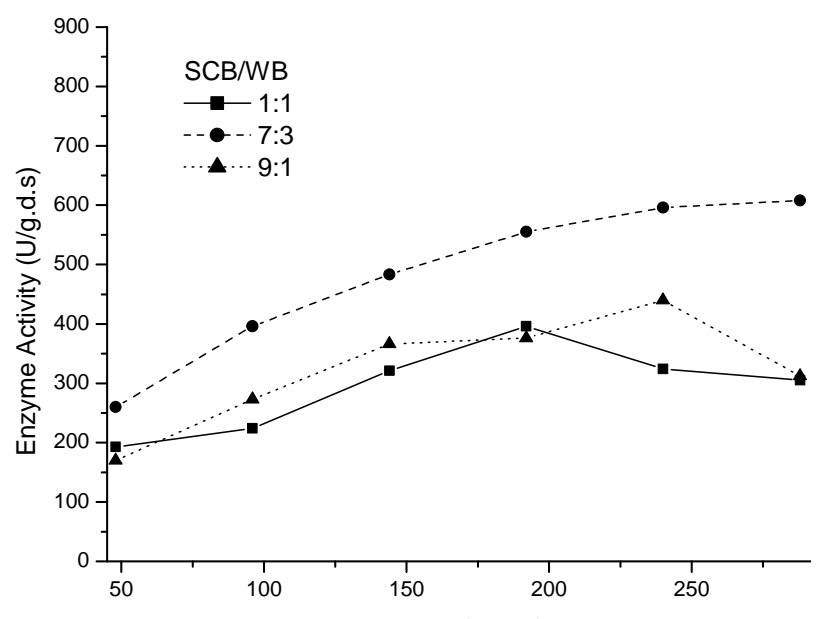

a)

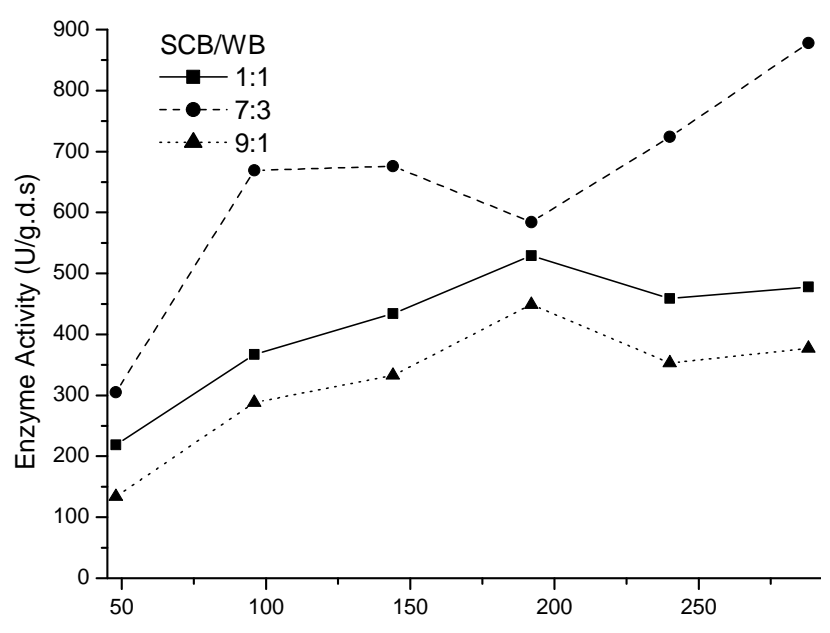

c)

Table 1 presents some results from literature using Myceliophtora strains cultivated in agro-industrial residues, where one may notice that the results here obtained for endoglucanase and FPase were much higher than the others, while the ones for xylanase were just as high, reveling that the isolated Myceliophtora sp. I-1D3b has a high potential for sugar cane bagasse hydrolysis, releasing hexosis and pentosis which could be fermented by yeasts in another process step to

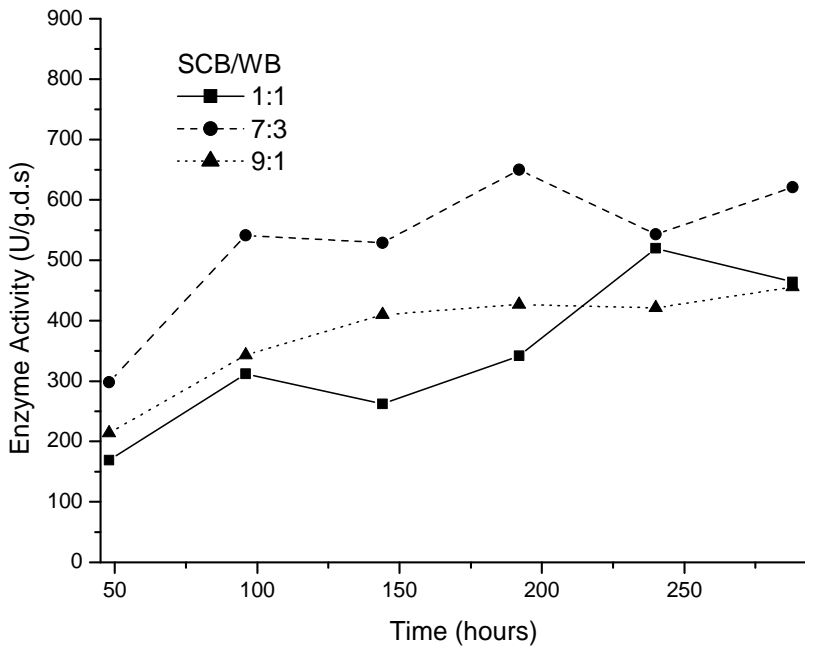

Figure 1. Endoglucanase activity in plastic bags by Myceliophtora $s p$ in medium containing different proportions of SCB/WB and $80 \%$ initial moisture content at different temperatures (a- $40^{\circ} \mathrm{C}$; b- $45^{\circ} \mathrm{C}$; c- $\left.50^{\circ} \mathrm{C}\right)$. produce ethanol of second generation. WB and SCB have different compositions and consequently different functions in fermentation. WB has $18 \%$ of proteins, $15 \%$ of cellulose, $43 \%$ hemicelluloses, $7 \%$ of lignin and a high level of phosphorus and nitrogen, while sugar cane bagasse has $45 \%$ of cellulose, $33 \%$ of hemicelluloses, $9 \%$ of lignin, and no protein (30). It is often assumed in literature that WB is a good substrate for SSF (24), since it provides the correct balance among carbon, 
nitrogen, phosphorus and micronutrients; hence, WB is often used to improve microbial growth.

According to Badhan et al. (3), Myceliophtora sp. (IMI 389099) produced considerable amounts of endoglucanase and xylanase using only SCB as substrate, and even higher quantities having WB as substrate (Table 1). Hence, experiments having WB, SCB or WB/SCB (1:1) as substrates had to be carried out. No fungal growth was observed for SCB, probably due to a low nutrient level. The activity of endoglucanase in medium with only
WB was comparable to the activity with SCB/WB at the proportion 1:1 up to $144 \mathrm{~h}$ of fermentation time, followed by a steep decrease of endoglucanase activity in WB and a steep increase in SCB/WB, as can be seen in Figure 2. Therefore, it is reasonable to suppose that Myceliophtora sp. secreted basal levels of extracellular endoglucanase at the early stages of fermentation when the sugar content of the medium was high (data not shown) and when this source of carbon was depleted the secretion of endoglucanase increased.

Table 1. Fibrolytic enzymes produced by Myceliophtora sp. strains as reported in literature

\begin{tabular}{|c|c|c|c|c|c|}
\hline \multirow{2}{*}{ Fungus } & \multirow[b]{2}{*}{ Substrate } & \multicolumn{3}{|c|}{ Enzyme (U/g.d.s.) } & \multirow[b]{2}{*}{ Ref } \\
\hline & & EG* & Xylanase & FPase & \\
\hline Myceliophthora sp. V2A2 & Rice straw & 31.3 & 590.2 & 0.63 & (27) \\
\hline Myceliophthora fergusii T41 & Rice straw & 36.7 & 884.7 & 2.29 & (27) \\
\hline Myceliophthora sp. MYC & Rice straw & 35 & 900.2 & 2.44 & (27) \\
\hline $\begin{array}{l}\text { Myceliophthora sp. IMI } \\
389099\end{array}$ & SCB & 6.62 & 620.1 & 0.70 & (3) \\
\hline $\begin{array}{l}\text { Myceliophthora sp. IMI } \\
389099\end{array}$ & WB & 26.6 & 128.9 & 0.74 & (3) \\
\hline Myceliophthora sp. I-1D3b & WB & 350 & - & - & This work \\
\hline Myceliophthora sp. I-1D3b & SCB - WB & 878 & 900 & 8.30 & This work \\
\hline
\end{tabular}

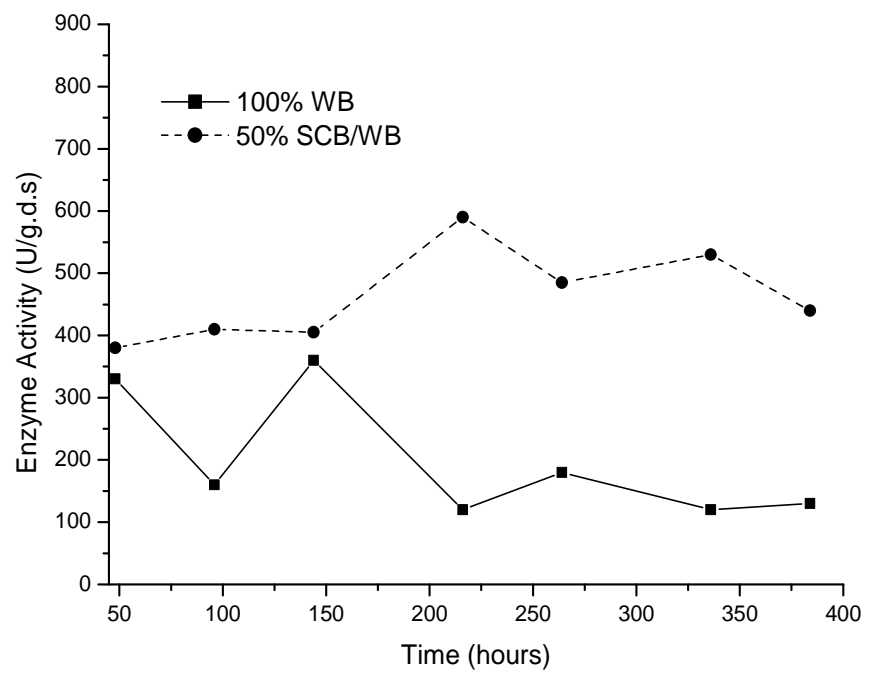

Figure 2. Endoglucanase activity in plastic bags using WB and a mixture of WB:SCB $(1: 1)$

Temperature seemed to influence endoglucanase activity only at the proportion 7:3 SCB/WB. High endoglucanase activities were obtained at $50^{\circ} \mathrm{C}$. The analysis of variance (ANOVA) showed that only the temperature, at $288 \mathrm{~h}$ of fermentation, significantly affected endoglucanase activity (at 85\% significance level), and that no other factor influenced such activity in shorter times. The mesophilic Aspergillus terreus M11 was cultivated by Gao et al. (10) in corn straw and the best endoglucanase activity was obtained at $45^{\circ} \mathrm{C}$, while Da Silva et al. (6) noticed the highest activity at $50^{\circ} \mathrm{C}$ for thermophilic Thermoascus auranticus Miehe cultivated in SCB, observing a steep decrease for higher temperatures.

Experiments varying the initial moisture content of the substrate were carried out at $45^{\circ} \mathrm{C}$ and $7: 3$ proportions $\mathrm{SCB} / \mathrm{WB}$; results are shown in Figure 3. No difference in the endoglucanase activity was observed when the moisture content was varied. A Tukey test was applied to the experimental results to assess the effect of the moisture content on endoglucanase activity in samples withdrawn at 
$48 \mathrm{~h}$ intervals. Only at $48 \mathrm{~h}$ was a difference observed (95\% significance level), and the results for $85 \%$ moisture content were worse than the ones for 75 and $80 \%$. Statistical differences among the treatments for all other fermentation times were not observed at 95\% significance level. For the highest moisture content, water might be filling the voids of the substrate, restricting mass transfer mechanisms (11). This is more evident during the early stages of the fermentation process, since the absorption of water by the substrates is slow, requiring at least six days to reach hygroscopic equilibrium (30).

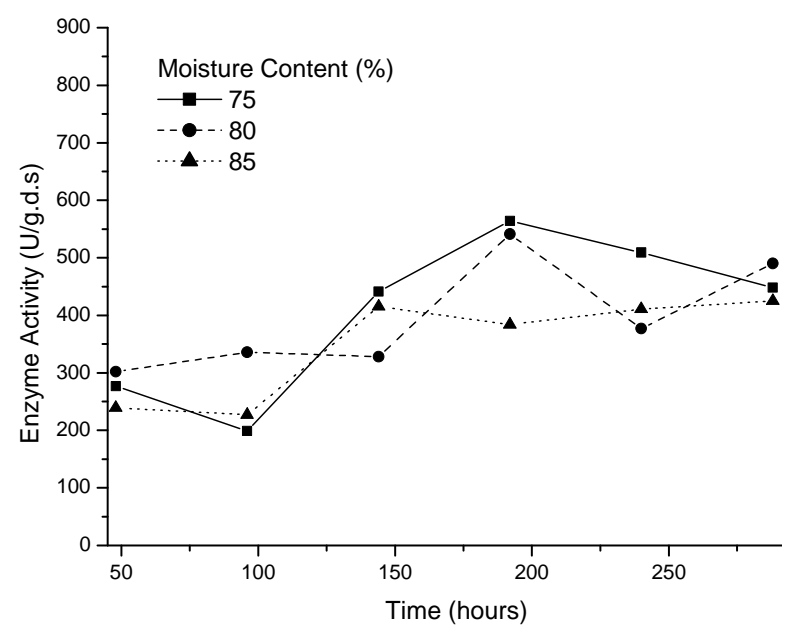

Figure 3. Endoglucanase activity in plastic bags at different initial moisture content, at $45^{\circ} \mathrm{C}$ and 7:3 SCB/WB proportion.

\section{Packed bed experiments}

Preliminary tests were performed in the packed bed using the best operational conditions obtained for plastic bag experiments $\left(50^{\circ} \mathrm{C}, 7: 3\right.$ SCB/WB proportion, $80 \%$ initial moisture content). However, it was noticed that water leaked from the bottom of the bed because it was not completely absorbed by the substrates at the beginning of the experiment. Hence, it was decided to use $75 \%$ moisture content in the following tests.

The longitudinal distributions of the moisture content and the endoglucanase activity after $144 \mathrm{~h}$ of experiment are displayed in Figure 4, where the horizontal axis represents the samples collected after the fermentation process. Knowing that the fermented material of each module was split into three samples, Sample 1 was collected in the axial position closest to bottom of the bed. Moisture content increased from the bottom to the top of the bed, while the enzyme activity suffered some variation in the first module, remained stable in the following two modules and steeply decreased in the last one. A similar trend was also observed by other authors $(1,7,14,18,29)$, although the drop in the upper module was more intense than any other presented in the literature.

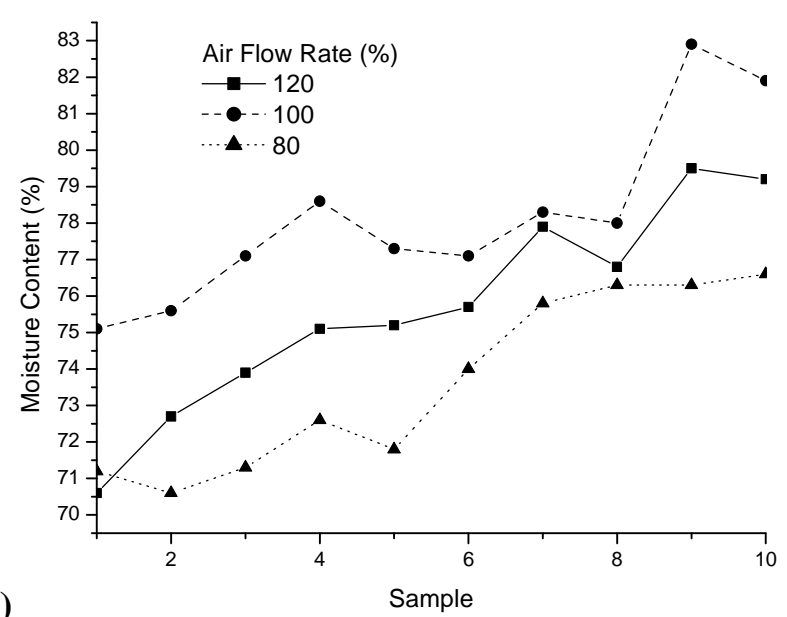

a)

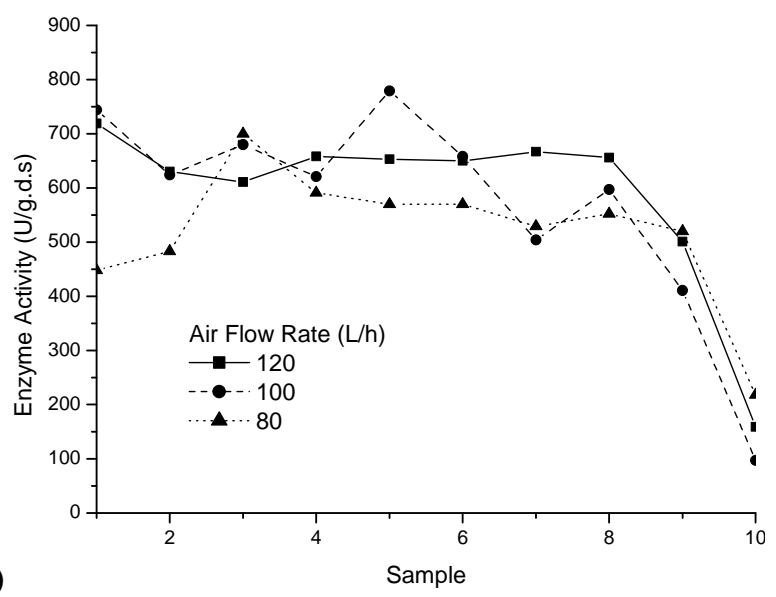

Figure 4. Longitudinal distribution of moisture content and endoglucanase activity in packed bed bioreactor after $144 \mathrm{~h}$ fermention time for 7:3 SCB/WB proportion, $50^{\circ} \mathrm{C}$ and $75 \%$ initial moisture content. (a- mositure content; b endoglucanase activity). 
The temperature of the saturated air at the upper module was about $6^{\circ} \mathrm{C}$ above the temperature set for the process (45 and $50^{\circ} \mathrm{C}$ ), while the laboratory temperature was kept at $30^{\circ} \mathrm{C}$. Such a temperature decreased driven water condensing, which dropped back to the bed. In this condition the microorganism did not grow properly, which was confirmed by visual observation, and the endoglucanase was not synthesized at the same high amount as in the lower portions of the bed. However, considering that at least three quarters of the bed produced high and stable quantities of endoglucanase, the system could be considered of interest for industrial purposes.

The flow rate did not influence the moisture content nor the endoglucanase activity, as can be seem in Figure 4 and was confirmed by a Tukey test at 95\% significance level. The same lack of influence was observed for the experiments carried out at $45^{\circ} \mathrm{C}$, although the endoglucanase activity was lower than for $50^{\circ} \mathrm{C}$, according to a Tukey test at $95 \%$ significance level.

The dynamic temperature profiles for experiments carried out at 45 and $50^{\circ} \mathrm{C}$ at $80 \mathrm{~L} / \mathrm{h}$ flow rate are presented in Figure 5. The noise observed in the signals provided by the thermocouples is typical of such a kind of experiment, from which one should not expect accuracy higher than $0.5^{\circ} \mathrm{C}(28)$. This Figure represents the actual temperature provided by the thermocouples subtracted from the bed wall temperature, thus only the temperature increase due to the fermentation process is displayed. Little spatial temperature variation was observed, indicating good thermal homogeneity, a very interesting industrial attribute.
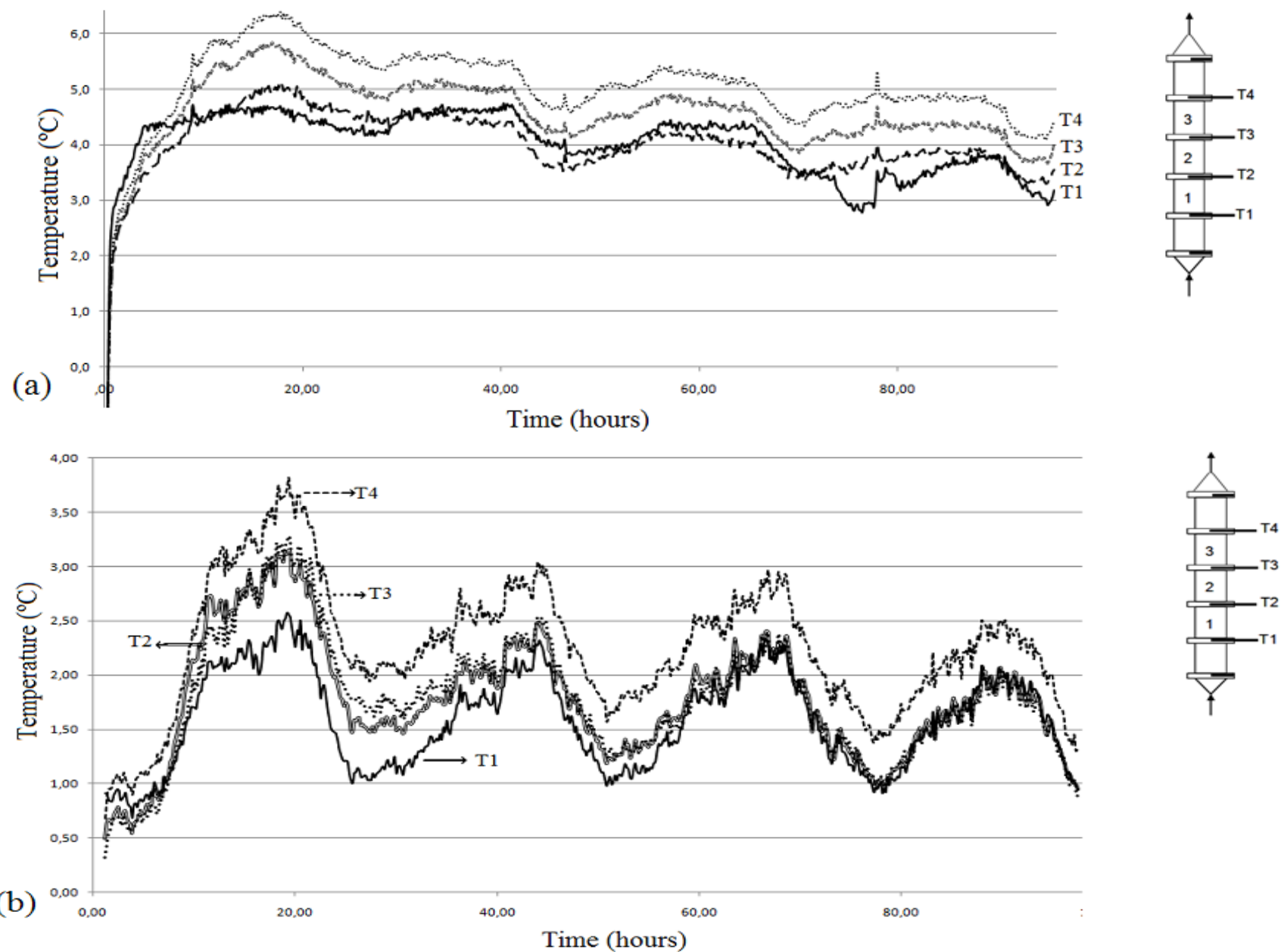

Figure 5. Longitudinal temperature distribution in the packed bed bioreactor during the fermentation process for enzyme production for 7:3 SCB/WB proportion, $75 \%$ initial moisture content and $80 \mathrm{~L} / \mathrm{h}$ air flow rate $\left(\mathrm{a}-45^{\circ} \mathrm{C}\right.$, b- $\left.50^{\circ} \mathrm{C}\right)$ 
At $50^{\circ} \mathrm{C}$ the peaks are less intense than at $45^{\circ} \mathrm{C}$, revealing that the fungus has higher activity at lower temperatures, even though the endoglucanase secretion at $50^{\circ} \mathrm{C}$ was higher, as pointed out earlier. The highest temperature peak was observed after 18h fermentation time, possibly indicating the end of the exponential growth phase. Such temperature increase is mild when compared with the increase reported in literature for mesophillic fungi, for which overheating of $15^{\circ} \mathrm{C}$ above the process temperature has already been observed (23).

\section{CONCLUSION}

The recently isolated fungus Myceliophtora sp I-1D3b produced high quantities of endoglucanase and also of filterpaper cellulase (FPase) and xylanase in plastic bag experiments, and high amount of endoglucanase in packed bed experiments, having sugar cane bagasse and wheat bran as substrates. The proportion sugar cane bagasse/wheat bran strongly influenced the endoglucanase activity, and the best results were obtained using a 7:3 SGB/WB proportion. Temperature is another key factor and the best results were obtained at $50^{\circ} \mathrm{C}$. High amounts of total cellulase FPase and xylanase were also observed, even though these enzymes were not the main focus of this article. During packed bed experiments, the temperature increase due to the microbial metabolism was mild, about $6^{\circ} \mathrm{C}$ above the process temperature, leading to a quite stable process, independent of the air flow rate in the range of 80 to $120 \mathrm{~L} / \mathrm{h}$. Therefore, the longitudinal endoglucanase activity profile was almost flat, and a sudden drop was noticed only at the top of the bed due to operational reasons. Such results are valuable since a highadded product could be produced in large amounts from cheap by-products, sugar cane bagasse and wheat bran, and using a relatively simple fermentor.

\section{ACKNOWLEDGEMENTS}

The authors thank the Brazilian research councils
FAPESP (procs. 2008/52811-4 and 2010/12624-0) and CNPq (INCT- Bioethanol) for financial support.

\section{REFERENCES}

1. Ahlawat, S.; Battan, B.; Dhiman, S.S.; Sharma, J.; Mandhan, R.P. (2007). Production of thermostable pectinase and xylanase for their potential application in bleaching of kraft pulp. J. Ind. Microb. Biotech., 34,763-770.

2. AP-Food Technology (2007). Asia drives Novozymes food enzyme growth. Available at: http://www.ap-foodtechnology.com/Formulation/ Asia-drives-Novozymes-food-enzyme growth. Accessed 15 January 2011.

3. Badhan, A.K.; Chadha, B.S.; Kaur, J.; Saini, H.S.; Bhat, M.K. (2007). Production of multiple xylanolytic and cellulolytic enzymes by thermophilic fungus Myceliophthora sp. IMI 387099. Bioresour. Tech., 98, 504-510.

4. Ben Romdhane, I.B.; Achouri, I.M.; Belghith, H. (2010). Improvement of highly thermostable xylanases production by Talaromyces thermophilus for the agro-industrials residue hydrolysis. Appl. Biochem. Biotechnol., 162, 1635-1646.

5. Cardona, C.A.; Quintero, J.A.; Paz, I.C. (2010). Production of bioethanol from sugarcane bagasse: status and perspectives. Bioresour. Technol., 101, 4754-4766.

6. Da Silva, R.; Lago, E.S.; Merheb, C.W.; Macchione, M.M.; Park, Y.K. (2005). Production of xylanase and CMCase on solid state fermentation in different residues by Thermoascus aurantiacus Miehe. Braz. J. Microbiol, 36, 235 - 241.

7. Foong, C.W.; Krishnaiah, K.; Janaun, J.; Subbarao, D.; Prabhakar, A. (2009). Heat and mass transfer studies of palm kernel cake (PKC) in fluidized bed fermenter. Ind. Crop. Prod., 30, 227-234.

8. Freedonia Group (2010). Enzymes US Industry Study with Forecasts for 2014 \& 2019. Available at: http://www.freedoniagroup.com/ brochure/26xx/2670smwe.pdf. Accessed 15 January 2011.

9. Gaffney, M.; Doyle, S.; Murphy, R. (2009). Optimization of xylanase production by Thermomyces lanuginosus in solid state fermentation. Biosc. Biotechnol. Biochem., 73, 2640-2644.

10. Gao, J.; Weng, H.; Zhu, D.; Yuan, M.; Guan, F.; Xi, Y. (2008). Production and characterization of cellulolytic enzymes from the thermoacidophilic fungal Aspergillus terreus M11 under solid-state cultivation of corn stover. Bioresour. Technol., 99, 7623-7629.

11. Gervais, P.; Molin, P. (2003). The role of water in solid-state fermentation. Biochem. Eng. J., 13, 85-101.

12. Ghose, T.K. (1987). Measurement of cellulases activities. Pure Appl. Chem., 59, 257 - 268.

13. Ghose, T.K.; Bisaria, V.S. (1987). Measurement of hemicellulases: 
activities part 1: xylanases. Pure Appl. Chem., 59, 1739 - 1752.

14. Gowthaman, M.K.; Raghavarao, K.S.M.S.; Ghildyal, N.P.; Karanth, N.G. (1993). Gas concentration and temperature gradients in a packed bed solid-state fermentor. Biotecnol. Adv., 11, 611-620.

15. Graminha, E.B.N.; Gongalves, A.Z.L.; Pirota, R.D.P.B.; Balsalobre, M.A.A.; Da Silva, R.; Gomes, E. (2008). Enzyme production by solidstate fermentation: Application to animal nutrition. Anim. Feed Sci. Tech., 144, 1-22.

16. Grigorevski-Lima, A.L.; Da Vinha, F.N.M.; Souza, D.T., Bispo, A.S.R.; Bon, E.P.S.; Coelho, R.R.R.; Nascimento, R.P. (2009). Aspergillus fumigatus thermophilic and acidophilic endoglucanases. Appl. Biochem. Biotechnol., 155, 321-329.

17. Haki, G.D.; Rakshit, S.K. (2003). Developments in industrially important thermostable enzymes: a review. Bioresour.Technol., 89, 1734.

18. Khanahmadi, M.; Roostaazad, R.; Mitchell, D.A.; Miranzadeh, M.; Bozorgmehri, R.; Safekordi, A. (2006). Bed moisture estimation by monitoring of air stream temperature rise in packed-bed solid-state fermentation. Chem. Eng. Sci., 61, 5654 -5663.

19. Mamma, D.; Kourtoglou, E.; Christakopoulos, P. (2008). Fungal multienzyme production on industrial by-products of the citrusprocessing industry, Bioresour. Technol., 99, $2373-2383$.

20. Miller, G.L. (1959). Use of dinitrosalicylic acid reagent for determination of reducing sugar. Anal. Chem., 31, 426-428.

21. Mishima, D.; Tateda, M.; Ike, M.; Fujita, M. (2006). Comparative study on chemical pretreatments to accelerate enzymatic hydrolysis of aquatic macrophyte biomass used in water purification processes. Bioresour. Technol., 97, 2166 - 2172.

22. Mishra, S.; Baranwal, R. (2009). Yeast genetics and biotechnological applications. In: Satyanarayana, T., Kunze, G. (eds). Yeast biotechnology: diversity and applications. Springer, New York.
23. Mitchell, D.A.; Cunha, L.E.N.; Machado, A.V.L.; Luz Jr, L.F.L.; Krieger, N. (2010). A model-based investigation of potential advantages of multi-layer packed beds in solid-state fermentation. Bioch. Eng. J., 48, 195-203.

24. Pandey, A.; Selvakumar, P.; Soccol, C.R.; Nigam, P. (1999). Solid state fermentation for the production of industrial enzymes. Curr. Sci., 77, 149-162.

25. Paturau, J.M. (2011). Alternative uses of sugarcane and its byproducts in agroindustries. FAO Corporate Document Repository. http://www.fao.org/docrep/003/s8850e/S8850E03.htm. Accessed 15 January 2011.

26. Singhania, R.R; Sukumaran, R.K; Patel, A.K.; Larroche, C.; Pandey, A. (2010). Advancement and comparative profiles in the production technologies using solid-state and submerged fermentation for microbial cellulases. Enz. Microb. Technol., 46, 541-549.

27. Soni, R.; Nazir, A.; Chadha, B.S.; Saini, H.S. (2008). Novel sources of fungal cellulases for efficient deinking of composite paper waste. Bioresour., 3, 234-246.

28. Thoméo, J.C.; Rouiller, C.O.; Freire, J.T. (2004). Experimental analysis of heat transfer in packed beds with air flow. Ind. Eng. Chem. Res., 43, $4140-4148$.

29. Umsza-Guez, M.A. (2009). Polygalacturonase production by solid state fermentation using the fungus Thermomucor indicae-sedaticae N31in glass flasks and in a fixed bed bioreactor. São José do Rio Preto, Brasil, 106p. (DSc. Thesis Instituto de Biociências, Letras e Ciências Exatas, UNESP). (in Portuguese).

30. Zanelato, A.I. Cellulolitic enzyme production by solid state fermentation in a fixed bed bioreactor. São José do Rio Preto, Brasil, 113p. (M.Sc. Dissertation. Instituto de Biociências, Letras e Ciências Exatas, UNESP). (in Portuguese). 